Didaktik : Jurnal Pendidikan Guru Sekolah Dasar, ISSN : 24775673

Sekolah Tinggi Keguruan dan IImu Pendidikan Subang

Volume IV Nomor 2, Desember 2018

\title{
MENINGKATKAN HASIL BELAJAR SISWA MELALUI MODEL PEMBELAJARAN KOOPERATIF TIPE TGT PADA MATERI NEGARA MAJU DAN NEGARA BERKEMBANG DI KELAS IX F SMP NEGERI 1 CIBOGO TAHUN 2017
}

\author{
Lilis Lisdiawati \\ SMPN 1 Cibogo
}

\begin{abstract}
ABSTRAK
Rendahnya minat siswa untuk belajar IPS yang berakibat pada rendahnya hasil akhir peserta didik dalam kegiatan pembelajaran menjadi alasan yang mendasari lahirnya penelitian ini. Subyek penerima tindakan adalah siswa kelas IX F SMP Negeri 1 Cibogo Tahun Pelajaran 2017/2018 yang berjumlah 34 siswa, sementara subyek pelaksana adalah peneliti. Jenis penelitian ini adalah Penelitian Tindakan Kelas (PTK) . Tehnik pengumpulan data yang digunakan dalam penelitian ini adalah lembar observasi, catatan dilapangan pada waktu melaksanakan tindakan, lembar wawancara, lembar penilaian individu setelah mengikuti pelajaran. Prosedur dalam penelitian ini ada empat tahap yaitu perencanaan, pelaksanaan, pengamatan dan refleksi. Penelitian ini dilakukan dengan dua siklus dimana tiap siklus dilakukan dalam dua kali pertemuan yang dilakukan untuk memperoleh data peningkatan aktivitas dalam pembelajaran IPS siswa. Hasil penelitian pembelajaran ini menunjukan bahwa sebelum adanya tindakan di peroleh rata-rata tingkat aktivitas siswa sebesar $14 \%$. Pada siklus 1 tingkat rata-rata aktivitas siswa meningkat menjadi $41 \%$. Pada siklus II tingkat rata-rata aktivitas siswa meningkat menjadi $79 \%$. Berdasarkan data hasil Tindakan Penelitian Kelas tersebut maka dapat disimpulkan bahwa dengan penerapan model pembelajaran Kooperatif Tipe TGT dapat meningkatkan hasil pembelajaran IPS pada materi Negara Maju dan Negara Berkembang di kelas IX F SMP Negeri 1 Cibogo Tahun pelajaran 2017/2018. Hal ini karena Model pembelajaran Kooperatif Tipe TGT mengandung unsur permainan sehingga dapat meningkatkan aktivitas belajar siswa baik secara kognitif, afektif, maupun psikomotorik.
\end{abstract}

Kata Kunci : Hasil Belajar, Model Pembelajaran Kooperatif Tipe TGT, dan Pembelajaran IPS

\section{A. Pendahuluan}

Pendidikan merupakan

suatu usaha sadar yang dilakukan

oleh individu untuk

mengembangkan kepribadian dan

potensinya baik dalam segi fisik, intelektual, emosional, sosial dan spiritual melalui proses pengalaman belajar. Pengalaman belajar yang dialami individu mendukung pembangunan dimasa mendatang, guna menghadapi dan 
memecahkan masalah kehidupan

masa yang akan datang.

Proses belajar mengajar merupakan bagian terpenting dalam pendidikan yang didalamnya terdapat guru sebagai pengajar dan siswa yang sedang belajar. Guru sebagai seorang pendidik harus bisa menciptakan suatu proses pembelajaran yang kreatif dan inovatif, hal ini bertujuan untuk mengetahui sejauh mana aktivitas siswa saat proses belajar mengajar dan meningkatkan hasil belajar siswa. Setiap kegiatan pembelajaran memerlukan metode dan model pembelajaran tertentu untuk mencapai hasil yang maksimal. Salah satu model pembelajaran yang mendukung tercapainya standar kompetensi adalah model pembelajaran Kooperatif tipe Team Games Tournament (TGT), dalam model ini melibatkan aktivitas seluruh siswa tanpa harus ada perbedaan status, peran siswa lebih aktif, berkelompok, bekerja sama dalam tim dan mengandung unsur permainan.
Berdasarkan observasi yang dilakukan di kelas IX F SMPN 1 Cibogo Subang pada bulan Oktober tahun 2017 menunjukan bahwa hasil belajar siswa mata pelajaran IPS masih rendah khususnya materi Negara Maju dan Negara Berkembang yang disebabkan oleh beberapa faktor diantaranya faktor psikis siswa seperti sakit, malas dan siswa yang cenderung pasif saat pelajaran. Berdasarkan latar belakang tersebut maka penulis merumuskan masalah dalam penelitian ini adalah : Bagaimanakah Model Pembelajaran Kooperatif tipe TGT pada materi Negara Maju dan Negara Berkembang dapat meningkatkan hasil belajar siswa dikelas IX F SMP Negeri 1 Cibogo tahun 2017?

Tujuan yang ingin dicapai dalam penelitian ini adalah Untuk meningkatkan hasil belajar siswa melalui Model Pembelajaran Kooperatif tipe TGT pada materi Negara Maju dan Negara Berkembang di kelas IX SMP Negeri 1 cibogo tahun 2017. 


\section{B. Metode Penelitian}

Penelitian ini dilaksanakan di SMPN 1 Cibogo Subang Jalan Raya Cibogo Kabupaten Subang pada semester ganjil tahun pelajaran 2017/2018. Jenis penelitian adalah penelitian tindakan kelas (PTK) yang dilakukan dengan dua siklus. Langkah - langkah dalam penelitian ini ada 4 tahap yaitu, perencanaan (Planning),

Pelaksanaan (Action), Pengamatan (Observation), Refleksi (Reflection). Subjek dalam penelitian ini adalah peserta didik kelas IX F sebanayak 34 orang, yang terdiri dari 17 siswi perempuan dan 17 siswa laki - laki.

\section{Pembahasan}

Keberhasilan program sangat ditentukan oleh perencanaan yang baik. Dalam setiap proses pembelajaran di sekolah setiap guru harus memilih strategi pembelajaran yang tepat, hal ini merupakan salah satu faktor terpenting bagi keberhasilan proses pembelajaran. Rencana pelaksanaan pembelajaran telah dibuat pada awal tahun pembelajaran dengan program program lainnya.

Kriteria

ketuntasan minimal(KKM) mata pelajaran IPS adalah 72, nilai KKM sekaligus sebagai indikator pelaksanaan yang harus dicapai oleh peserta didik, apabila peserta didik telah mencapai nilai tersebut maka peserta didik tersebut dinyatakan tuntas atau lulus untuk SK, KD dan indikator yang telah ditentukan.

Dalam

pelaksaan pembelajaran ini sekaligus dilaksanakan observasi awal untuk mengidentifikasi permasalahan yang timbul dan cara pemecahannya selama proses pembelajaran berlangsung kegiatan pembelajaran dibagi kedalam 3 bagian yaitu : kegiatan awal, kegiatan inti dan kegiatan akhir. Pada kegiatan awal guru melakukan kegiatan pendahuluan berupa pengkondisian kelas, apersepsi materi pelajaran sebelumnya, dan motivasi belajar untuk materi berikutnya. Kegiatan inti merupakan kegiatan yang paling penting dalam proses kegiatan belajar mengajar, 
Didaktik : Jurnal Pendidikan Guru Sekolah Dasar, ISSN : 24775673

Sekolah Tinggi Keguruan dan IImu Pendidikan Subang

Volume IV Nomor 2, Desember 2018

kegiatan ini ditetapkan dalam 2

siklus, siklus pertama kegiatan

pembelajaran tanpa mengunakan

model pembelajaran kooperatif tipe

TGT, sedangkan siklus ke dua kegiatan belajar menggunakan model pembelajran kooperatif tipe TGT.

Alur pembelajaran Kooperatif tipe TGT seperti yang sudah dijelaskan dalam buku (Slavin, 2000) bahwa pembelajaran kooperatif tipe TGT terdiri dari 4 tahap, yaitu : (1) penyajian kelas, (2) Belajar team, (3) game tournament, (4) penghargaan Team.

Pertama penyajian kelas, diawali dengan guru membuka pelajaran, memberikan materi dengan metode ceramah, diskusi pada saat penyajian kelas siswa harus benar - benar memperhatikan dan memahami materi yang disampaikan oleh guru, sehingga dapat membantu siswa bekerja lebih baik pada saat kerja kelompok dan pada saat game, kemudian guru menutup dengan refleksi.
Kedua yaitu berlajar team, guru membagi siswa dalam enam kelompok dalam tipe TGT. Siswa kelas IX F yang berjumlah 34 orang dibagi kedalam enam kelompok, dimana nama kelompoknya merupakan nama - nama Negara. Setiap kelompok terdiri dari 5 atau 6 siswa dengan kemampuan yang heterogen dan berdasarkan nilai yang diperoleh dari daftar nilai guru. Guru menyiapkan soal - soal yang simasukan kedalam amplop dibagi sesuai kriteria tingkat kesulitan yang berbeda. Dalam kelompok heterogen siswa memilih wakil kelompoknya dimeja turnamen, meja turnamen sendiri terdiri dari enam meja dimana setiap kelompok heterogen bisa mengajukan satu orang anggota untuk bisa main di meja turnamen dalam pengajuan wakil kelompok guru memberi arahan sesuai dengan tingkat kemampuan akademik siswa.

Kemudian siswa masuk kedalam meja turnamen, guru menyiapkan enam soal dan enam jawaban,dan lembar skor yang diberi nama dan jumlah skor siswa. 
Guru menjelaskan bagaimana kriteria pencatatan skor. Permainan dimulai disalah satu meja, siswa mengambil satu amplop yang berisi pertanyaan dan jawaban yang disiapkan oleh guru, kemudian siswa membacakan soal tersebut, setelah soal selesai dibaca, peserta yang lain berebut menjawab dengan mengacungkan tangan, kemudian pembaca soal berhak menentukan siapa yang bisa menjawab soal terlebih dahulu. Begitu seterusnya permainan berlangsung dan dihitung skor individu yang di dapat dari meja permainan dan kemudian permainan selesai saat semua soal dibaca dan dijawab.

Setelah game tournament selesai, guru memberi arahan pada siswa untuk melaporkan skor yang didapat pada meja permainan ke kelompok heterogen dan guru mencatat skor permainan di papan tulis. Setelah diketahui semua skor, guru memberi tambahan soal yang akan didapat masing- masing tim heterogen 1 soal untuk dijawab sebagai tambahan skor, akan tetapi jika tim yang mendapat soal tidak bisa menjawab soal maka boleh diperebutkan tim lain, setelah pencatatan skor akhir maka akan diketahui kelompok siapa yang akan memenangkan semua game. Setelah itu guru memberi apresiasi tambahan nilai kepada kelompok yang berhasil memenangkan game. Berdasarkan hasil pengamatan dan dari pernyataan pesertadidik mengenai jalannya pembelajaran, dapat diambil kesimpulan bahwa :

1. Peserta didik banyak mengalami kesulitan dalam menjawab pertanyaan yang diberikan oleh guru,

2. Kurangnya aktifitas belajar peserta didik karena model pembelajaran yang cenderung monoton dan membosankan.

Dari pengamatan dan refleksi terhadap pembelajaran siklus pertama, dijadikan dasar untuk membuat rencana pembelajaran siklus berikutnya, antara lain dengaan modifikasi :

1. Peserta didik diberi tugas individu untuk mengamati tentang Karakteristik Negra Maju dan Negara Berkembang, 
Didaktik : Jurnal Pendidikan Guru Sekolah Dasar, ISSN : 24775673

mengapa mereka melakukan

kegiatan tersebut dan untuk apa

mereka melakukan kegiatan tersebut.

2. Guru menyiapkan perencanaan pembelajaran siklus berikutnya.

3. Guru mendesain ruang belajar supaya menarik.

4. Guru menyiapkan segala peralatan dan perlengkapan untuk perbaikan siklus berikutnya.

Dari hasil penelitian yang dilakukan dalam dua siklus terdapat perbandingan hasil tes yang diperoleh siswa pada siklus kesatu dan siklus kedua, sebagaimana yang tercantum pada tabel berikut ini :

Tabel 1.

Perbandingan nilai siswa pada siklus 1 dan siklus 2

\begin{tabular}{|c|c|c|c|}
\hline \multirow{2}{*}{ No } & \multirow{2}{*}{ Nilai } & \multicolumn{2}{|c|}{$\mathbf{N}$} \\
\hline & & Siklus 1 & Siklus 2 \\
\hline 1 & 100 & - & - \\
\hline 2 & 95 & - & - \\
\hline 3 & 90 & - & 4 \\
\hline 4 & 85 & - & 2 \\
\hline 5 & 80 & 2 & 10 \\
\hline 6 & 75 & 12 & 11 \\
\hline 7 & 70 & 12 & 4 \\
\hline 8 & 65 & 6 & 3 \\
\hline 9 & 60 & 2 & - \\
\hline \multicolumn{2}{|c|}{ Jumlah siswa } & 34 & 34 \\
\hline \multicolumn{2}{|c|}{ Rata - rata } & 70,88 & 77,35 \\
\hline
\end{tabular}

Tabel 2.

Perbandingan hasil tes siklus 1 dan siklus 2 (ketuntasan hasil belajar siswa)

\begin{tabular}{|l|c|c|}
\hline Karakteristik & Siklus 1 & Siklus 2 \\
\hline $\mathrm{N}$ & 34 & 34 \\
\hline$\sum$ siswa yang tuntas $>72$ & 14 & 27 \\
\hline $\begin{array}{l}\Sigma \text { siswa yang belum tuntas } \\
<72\end{array}$ & 20 & 77,35 \\
\hline Rata - rata & 70,88 & $79 \%$ \\
\hline Ketuntasan(\%) & $41 \%$ & \\
\hline
\end{tabular}


Dari hasil penilaian melalui pengamatan dan observasi selama proses pembelajaran berlangsung, diperoleh data-data sebagai berikut:

1. Siklus Pertemuan pertama

Hasil penilaian selama proses pembelajaran berlangsung tanpa menggunakan model pembelajaran Kooperatif TGT diperoleh data bahwa dari 34 peserta didik yang dinyatakan tuntas sebanyak 14 orang ( $41 \%)$, peserta didik yang belum tuntas sebanyak 20 orang (59\%).

2. Siklus pertemuan kedua

Hasil penilaian selama proses pembelajaran berlangsung dengan menggunakan model pembelajaran Koperatif Tipe TGT menunjukan adanya peningkatan hasil belajar yang ditunjukan dengan data dari 34 peserta didik sebanyak 27 peserta didik (79\%) dinyatakan nilainya diatas KKM atau tuntas, peserta didik yang belum tuntas sebanyak 7 orang (21\%).

Berdasarkan hasil pertemuan pertama dan kedua terdapat peningkatan, dari 14 orang yang tuntas pada pertemuan pertama menjadi 27 orang yang tuntas pada pertemuan kedua., sedangkan nilai proses perilaku siswa yang mengikuti pembelajaran pada siklus pertama $26 \%$ menjadi $76 \%$ . Hal ini menunjukan penggunaan model pembelajaran Kooperatif Tipe TGT efektif untuk meningkatkan aktifitas belajar peserta didik.

\section{Kesimpulan}

Kesimpulan yang dapat diambil dari penelitian ini antara lain : Terdapat kenaikan hasil belajar pada pertemuan kedua setelah menggunakan Model pembelajaran Kooperatif Tipe TGT yang semula siklus pertama 14 orang $(41 \%)$ yang tuntas menjadi 27 orang (79\%), di mana KKM IPS adalah 72 .

Dengan demikian penggunaan model pembelajaran Kooperatif Tipe TGT pada materi Negara Maju dan Negara Berkembang terbukti secara signifikan dapat meningkatkan hasil belajar siswa di kelas IX F SMP Negeri 1 Cibogo, tahun 2017. 
Didaktik : Jurnal Pendidikan Guru Sekolah Dasar, ISSN : 24775673

\section{DAFTAR PUSTAKA}

Ahmadi, dkk. 2011. Strategi Pembelajaran Sekolah

Terpadu. Jakarta: Prestasi

Pustaka Publisher.

Arikunto, Suharsimi. 2010.

Prosedur Penelitian.

Jakarta: Rineka Cipta.

Arikunto, Suharsimi. 2006.

Prosedur Penelitian.

Jakarta: Rineka Cipta.

A M. Sardiman. 2010. Interaksi \&

Motivasi Belajar Mengajar.

Jakarta: Rajawali Press.

Depdiknas. 2009. Undang- undang

Sistem Pendidikan Nasional.

Yogyakarta:

Pustaka Pelajar.

Depdiknas. 2001. Kamus Besar

Bahasa Indonesia. Jakarta:

Balai Pustaka.

Dimyati dan Mudjiono. 2006.

Belajar dan Pembelajaran.

Jakarta: Rineka Cipta.

Djamarah, Bahri Syaiful dan Zain,

Aswan. 2010. Strategi

Belajar Mengajar.

Jakarta: Rineka Cipta.

E. Mulyasa. 2009. Menjadi Guru

Profesional Menciptakan

Pembelajaran Kreatif dan
Menyenangkan. Bandung:

Remaja Rosdakarya.

Firman, Harry. 1987.

Keefektifan

Program

Pembelajaran.

http://ahmadmuhli.wordpres

s.com/2011/08/02/efektivita

s-pembelajaran/

Diakses September 2017.

Lijan Poltak, Sinambela. 2006.

Reformasi Pelayanan

Publik: Teori, Kebijakan,

dan Implementasi. Jakarta:

PT. Bumi Aksara

Salim, Peter. 1991. Kamus Besar

Bahasa Indonesia. Jakarta: Balai

Pustaka

Sapriya. 2009. Pendidikan IPS.

Bandung: PT Remaja Rosdakarya.

Slameto. 2010. Belajar \& Faktor-

Faktor yang mempengaruhi. Jakarta: Rineka Cipta.

Slavin, Robert E., 1995.

Cooperative Learning: Teory,

Research, and Practice.

Secon Edition.

Massachusetts: Ally and Bacon Publishers.

Sudjana, Nana. 2013. Dasar-Dasar

Proses Belajar Mengajar. 
Didaktik : Jurnal Pendidikan Guru Sekolah Dasar, ISSN : 24775673 Sekolah Tinggi Keguruan dan IImu Pendidikan Subang Volume IV Nomor 2, Desember 2018

Bandung: Sinar Baru
Algesindo.

Sugiyono. 2013. Metode Penelitian

Pendidikan Kuantitatif Kualitatif dan $R \& D$.

Bandung: Alfabeta.

Sugiyono. 2008. Metode Penelitian

Pendidikan Kuantitatif Kualitatif dan

$R \& D$.

Bandung: Alfabeta.

Suprijono, Agus. 2009. Cooperative

Learning. Yogyakarta. Pustaka

Pelajar.
Rusman. 2011. Model- model Pembelajaran

Mengembangkan

Profesionalisme Guru. Jakarta: PT.Rajagrafindo Persada.

Wina,Sanjaya.2008. Strategi Pembelajaran Berorientasi Standar Proses Pendidikan. Jakarta: Kencana Prenada Media. 